\title{
Is Tuber brumale a threat to $T$. melanosporum and T. aestivum plantations?
}

\author{
Francesca Ori ${ }^{(1)}$, \\ Pamela Leonardi (2), \\ Enrico Stagnini ${ }^{(1)}$, \\ Valentina Balestrini ${ }^{(2)}$, \\ Mirco lotti ${ }^{(1)}$, \\ Alessandra Zambonelli ${ }^{(2)}$
}

\begin{abstract}
True truffles in the genus Tuber are the most valuable ectomycorrhizal fungi and their cultivation has become widespread around the world. Competition with other ectomycorrhizal fungi and especially with undesired Tuber species, like $T$. brumale, can threaten the success of a truffle plantation. In this work, the competitiveness of $T$. brumale towards $T$. melanosporum and $T$. aestivum was assessed in a 14 year-old plantation carried out planting seedlings inoculated with these three truffle species in adjacent plots. Analyses of both truffle ectomycorrhizas and extra-radical mycelium were carried out in the transects separating the $T$. brumale plot from $T$. melanosporum and $T$. aestivum plots. The results confirm the competitiveness of $T$. brumale against $T$. aestivum and T. melanosporum due to its major ability to colonize the soil around its ectomycorrhizas. However, its competitiveness is limited to the transect areas and it was never found inside T. melanosporum plot. These results remark that, in presence of optimal conditions for T. melanosporum and T. aestivum, the greatest risk of contamination with $T$. brumale is due to wrong greenhouse activity.
\end{abstract}

Keywords: Competition, Black Truffles, Extra-Radical Mycelium, Ectomycorrhizas, Species-Specific Primers ectomycorrhizal fungi, and different plantfungus pairings can result in notable modifications in performance for both symbionts (Bever 2002, Nara 2006). Competition between ectomycorrhizal fungi becomes of practical relevance when a commercially valuable fungus is introduced in the field through inoculated seedlings obtained in greenhouse. ECMs of the introduced fungal species can be replaced by other native ectomycorrhizal fungi on the host roots (Hall et al. 2007) and threaten the success of the plantation.

True truffles in the genus Tuber are the most valuable ectomycorrhizal fungi and their cultivation has become widespread around the world (Zambonelli et al. 2017). The most cultivated Tuber species are the black truffles Tuber melanosporum Vittad., T. aestivum Vittad. and, to a lesser extent, T. brumale Vittad. These species often share the same natural sites and compete
(1) Department of Life, Health and Environmental Sciences, University of L'Aquila, I67100 L'Aquila (Italy); (2) Department of Agricultural and Food Sciences, University of Bologna, v.le Fanin 46, I-40127 Bologna (Italy)

@ Mirco lotti (mirco.iotti@univaq.it)

Received: Mar 13, 2018 - Accepted: Sep 05, 2018

Citation: Ori F, Leonardi P, Stagnini E, Balestrini V, lotti M, Zambonelli A (2018). Is Tuber brumale a threat to T. melanosporum and T. aestivum plantations? iForest 11: 775-780. doi: 10.3832/ifor2785-011 [online 2018-11-28]

Communicated by: Alberto Santini for space on the host roots (Hall et al. 2007, Chevalier \& Sourzat 2012). Due to the lower value of the ascomata and the high competitiveness, T. brumale has often replace the ECMs of $T$. melanosporum in greenhouse or in truffle plantations (Merényi et al. 2016). Most of the studies on ectomycorrhizal communities of T. melanosporum plantations carried out in Italy, France and Spain report the presence of $T$. brumale (De Miguel et al. 2014). It was also found able to compete with, and in some cases to replace, T. melanosporum in New Zealand and Australia where true truffles are not endemic and $T$. brumale was probably introduced with the inoculum (GuerinLaguette et al. 2013, Linde \& Selmes 2012). ECMs of T. brumale were also identified in T. aestivum plantations (Zambonelli et al. 2005, Benucci et al. 2011) but competition between these two black truffles has been poorly investigated. Rather, Tuber aestivum was found replacing T. melanosporum in several black truffle plantations around the world (Bencivenga et al. 1992, Granetti \& Angelini 1992, Turgeman et al. 2012, De Miguel et al. 2014).

Most of the studies focusing on the comered the distribution of their ECMs, while the extra-radical mycelium (ERM) has been little considered, as it is a relatively new target of investigation. Recent studies have shown that the use of species-specific primers on DNA extracted from soil is a sensible and reliable method to identify (Zampieri et al. 2010) or quantify (lotti et al. been considered as a contaminant, able to petition between black truffles only consid- 


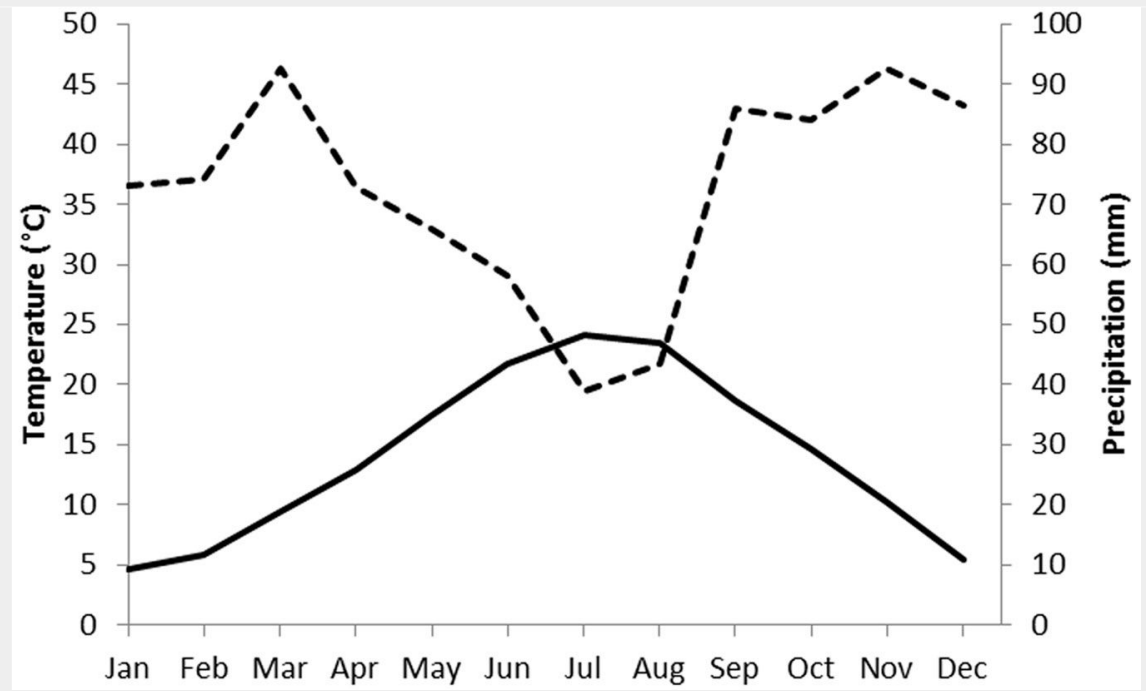

Fig. 1 - Climatic diagram of Bagnouls-Gaussen for the meteorological station of Montelabbate (Pesaro-Urbino, central Italy). Precipitation and temperature data are for the 2000-2016 period. Monthly temperatures (left axis, ${ }^{\circ} \mathrm{C}$ ) are indicated with the solid line, monthly precipitations (right axis, $\mathrm{mm}$ ) are indicated with the dotted line.

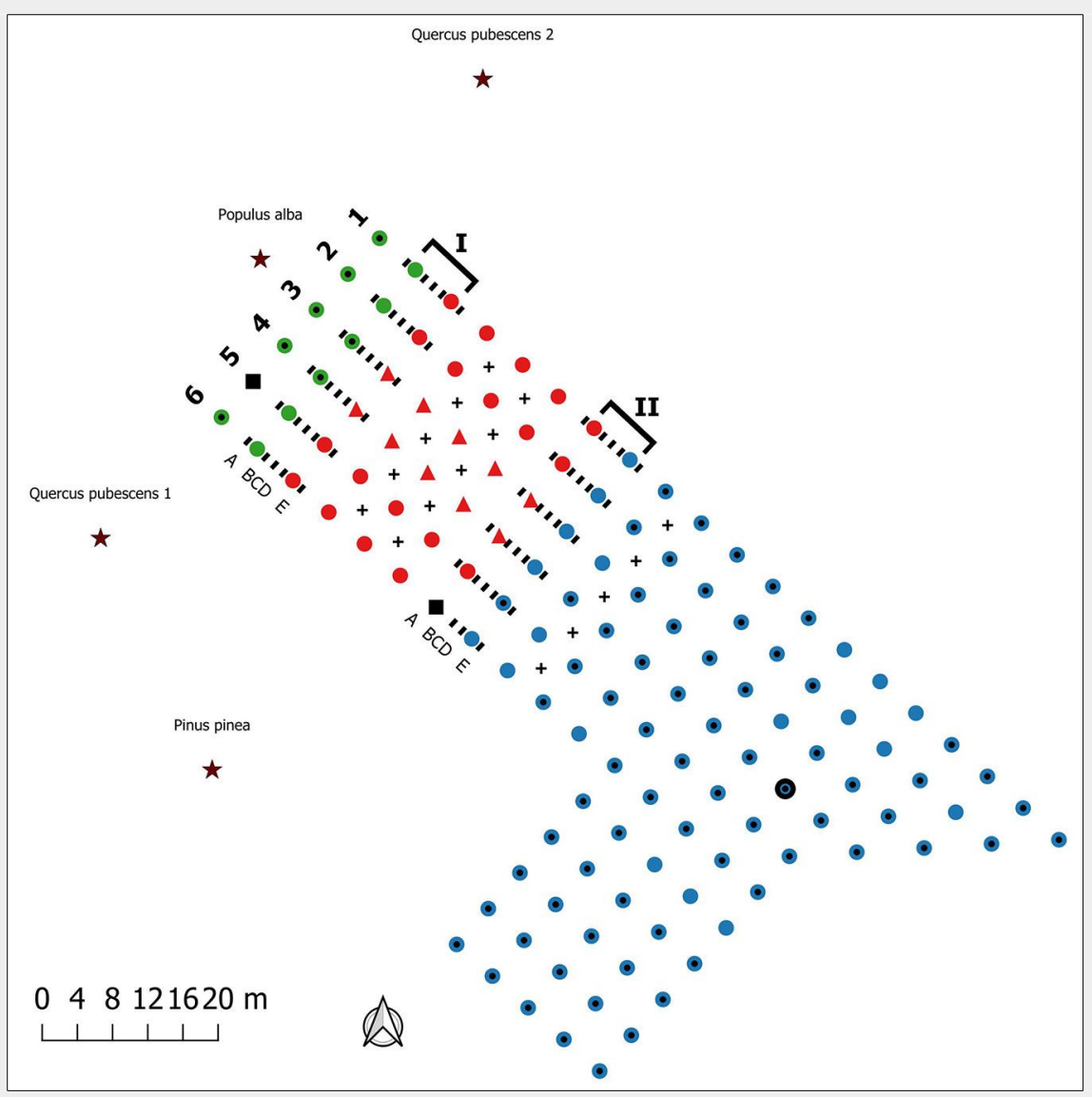

Fig. 2 - Scheme of truffle plantation, transect location and sampling points. Circles indicate Quercus pubescens seedlings; triangles Corylus avellana seedlings; black squares dead plants. Mycorrhized species: Tuber brumale (red), Tuber aestivum (green) Tuber melanosporum (blue). Dotted circles indicate plants with brûle and the bold circle indicates the only productive plant. Transects are highlighted with a square bracket: (I) aest/brum transect; (II) brum/mela transect. The positions of soil samples collected in each transect are indicated with the "-" symbol. (A-B-C-D-E): soil sample types: $A$ and $E$ were only used for ERM analysis, while $B, C$ and $D$ for both ERM and ECMs analyses. Sampling within plots are indicated with "+" symbol. The black star symbol indicates the adult ectomycorrhizal trees surrounding the plantation: Quercus pubescens 1, Quercus pubescens 2, Populus alba and Pinus pinea.
2012, Parladé et al. 2013, Gryndler et al. 2013) the ERM of a Tuber species in soil samples.

In the past, a number of plantations were established in Italy by planting groups of seedlings mycorrhized with different black truffles species in the same field (BaciarelliFalini et al. 2010). This kind of orchard is well suited to study the competitiveness between the different truffle species because they are subjected to the same experimental conditions. In one of these plantations, we aimed to verify the competitiveness of $T$. brumale towards T. melanosporum and $T$. aestivum 14 years after planting. Analyses of both truffle ECMs and ERM were carried out in the transects separating T. brumale from T. melanosporum and T. aestivum plots.

\section{Materials and methods}

The study site covers an area of $1540 \mathrm{~m}^{2}$, at an altitude of about $80 \mathrm{~m}$ a.s.l., in the municipality of Montelabbate (Pesaro-Urbino, Italy $-43.845488 \mathrm{~N} ; 12.788349 \mathrm{E}$ ). The truffle orchard under investigation was established in 2002, using plants mycorrhized by spores. The field had been used for arable crops for at least 30 years before planting. The sandy-clay-loam soil (sand $49 \%$, clay $28 \%$, silt $23 \%$ ) is calcareous (total carbonate $22 \%$ ) and has a pH of 7.75 . The soil organic matter is $1.2 \%$. The climate of this area is characterized by a short summer drought period (Fig. 1); March and November are the wettest months while July $\left(24.1^{\circ} \mathrm{C}\right)$ and January $\left(4.7^{\circ} \mathrm{C}\right)$ are the hottest and coldest months, respectively. The region is suited to $T$. melanosporum, $T$. brumale and T. aestivum, which can also naturally occur in the same forest stands.

A total of 130 seedlings (120 Quercus pubescens Willd. and 10 Corylus avellana L.) mycorrhized with $T$. melanosporum, $T$. brumale or T. aestivum were planted $4 \times 4 \mathrm{~m}$ apart as shown in Fig. 2. The seedlings were certified by the regional authority ASSAM (Agenzia Servizi Settore Agroalimentare Marche, Osimo AN, Italy) which ensured a minimum mycorrhization of $30 \%$ with the target truffle species. At the time of the study, the plantation was grass-covered and the planted trees were 3 to $4 \mathrm{~m}$ high with a canopy cover of approximately 50\% (Fig. S1 in Supplementary material). Most of the plants mycorrhized with $T$. melanosporum (79\%) and T. aestivum (64\%) showed the characteristic brûlé (a vegetation-devoid area around the host plant), while the $T$. brumale plants did not show it. The plantation was surrounded by mature tree species, some of them ectomycorrhizal such as Q. pubescens, Populus alba L. and Pinus pinea $\mathrm{L}$. The only cultural practices carried out on the truffle orchard after planting were pruning, grass-mowing and irrigation. No tillage was performed. Irrigation was provided during summer by a drip system for the first 3 years after planting and, subsequently, by a sprinkler system every two weeks. 
At the time of the study, only one ascoma of $T$. melanosporum was collected (February 2016) under a plant mycorrhized with the same truffle species (Fig. 2).

\section{Soil sampling}

The soil sampling was carried out in late spring 2016 within two transects between the plots of plants mycorrhized with different Tuber species (Fig. 2): T. aestivum - T. brumale (I: aest/brum) and T. brumale - T. melanosporum (II: brum/mela).

The plants on the margins of the two transects (23 plants in total because one plant died) were selected for soil sampling. Only 3 out of 23 plants on the margin of the two transects shown a brûle (two in the aest/brum transect and one in the brum/ mela transect). Five sample types (A to $E$ ) were collected along each tree row as showed in Fig. 2. Samples were $1 \mathrm{~m}$ ( $B$ and $D)$ and $2 \mathrm{~m} \mathrm{(C)} \mathrm{far} \mathrm{from} \mathrm{the} \mathrm{trunks} \mathrm{into} \mathrm{the}$ transect areas, while samples $A$ and $E$ were $1 \mathrm{~m}$ far from the trunks into the respective truffle plots. Samples B to D were used for both ERM and ECM analyses while samples $A$ and $E$ were used only for ERM analysis. The 58 soil cores for ERM analysis ( 5 cores $\times 6$ rows $\times 2$ transects, excluding 2 cores not collected close to the dead plant) were extracted through disposable PVC tubes (30 cm depth and $20 \mathrm{~mm}$ in diameter, 0.1 $\left.\mathrm{dm}^{3}\right)$ to avoid cross contamination. The 35 soil cores for ECM analysis ( 3 cores $\times 6$ rows $\times 2$ transects, excluding 1 core not collected close to the dead plant) were extracted through a steel soil corer $(15 \mathrm{~cm}$ depth and $10 \mathrm{~cm}$ in diameter, $\sim 1.2 \mathrm{dm}^{3}$ ). Five and ten soil samples were also collected within T. melanosporum and T. brumale plots, respectively, to assess the presence/absence of truffle ECMs and ERMs. These samples were taken as described above, following the scheme reported in Fig. 2.

\section{Analysis of truffle ectomycorrhizas}

The roots were removed from the soil cores by a $2 \mathrm{~mm}$ mesh sieve, washed in sterile water and then examined under a stereomicroscope $(\times 20)$. The ECMs were assigned to T. aestivum, T. brumale, T. melanosporum or other fungal species on the basis of their morphology (Agerer 1995). When morphotyping was not able to distinguish $T$. brumale and T. melanosporum ECMs (e.g., lacking in cystidia), molecular identification was carried out by applying a direct PCR approach (lotti \& Zambonelli 2006) using the species-specific primers designed by Rubini et al. (1998).

The degree of infection was measured by counting the number of living ECMs of each morphotype in all the root samples and expressing the results as a percentage on the total number of ECMs examined.

Analysis of truffle extra-radical mycelia Soil cores collected for ERM analysis were extracted from the PVC tubes and transferred to $15 \mathrm{ml}$ tubes, taking care to avoid cross contamination. Any root fragments were removed under a stereomicroscope. The soil was stored at $-80{ }^{\circ} \mathrm{C}$ and lyophilized for three days using a Virtis Benchtop $2 \mathrm{~K}^{\circledast}$ freeze dryer (SP Industries, Warminster, PA, USA). After drying, soils were ground in a mortar and stored at $-20^{\circ} \mathrm{C}$ pending further DNA analyses.

The DNA was isolated from the soil samples using the protocol developed by lotti et al. (2012), adapted for $0.5 \mathrm{~g}$ of soil. Yield and quality of isolated soil DNAs were evaluated by a Nanodrop ${ }^{\circledR}$ ND-1000 (Thermo Fisher Scientific, Waltham, MS, USA).

The presence/absence of the ERM of the target truffle species was verified by using species-specific primers. The primer pair Uncl-Uncll (Mello et al. 2002) was used to detect $T$. aestivum while the presence of $T$. brumale and T. melanosporum was verified by a multiplex PCR approach using ITSB and ITSML as forward primers and ITS4LNG as the sole reverse primer (Rubini et al. 1998). PCRs targeting T. brumale and T. melanosporum ERMs were repeated separately with the primer pair combinations ITSB-ITS4LNG and ITSML-ITS4LNG, respectively, to allow the amplification of the low amount of target DNAs that remained undetected by multiplex PCRs.

PCRs were conducted using a T-gradient Thermal Cycler (Biometra, Göttingen, Germany) in a $30 \mu \mathrm{L}$ mixture volume containing $300 \mathrm{nM}$ each primer, $50 \mathrm{ng} \mathrm{DNA}, 1 \mathrm{U} \mathrm{Ex}$ Taq ${ }^{\circledast}$ DNA polymerase (Takara Bio Inc., Kusatsu, Japan), 1× Buffer solution, $200 \mu \mathrm{M}$ dNTP, $4 \mathrm{mM} \mathrm{MgCl} 2,10 \mu \mathrm{g}$ of Bovine Serum Albumine.

The cycling parameters were as follows: 3 min of initial denaturation step at $95^{\circ} \mathrm{C}$, followed by 23 cycles of $30 \mathrm{~s}$ at $94{ }^{\circ} \mathrm{C}, 30 \mathrm{~s}$ at $63{ }^{\circ} \mathrm{C}, 45 \mathrm{~s}$ at $72{ }^{\circ} \mathrm{C}$ and a final extension step at $72{ }^{\circ} \mathrm{C}$ for $7 \mathrm{~min}$.

\section{Results}

\section{Transect I - aest/brum}

A total of 5115 ECMs were counted in the 18 soil samples collected in the aest/brum transect. More than half the ECMs $(60 \%)$ belonged to the target Tuber species ( $32 \%$ T. brumale and $28 \% \mathrm{~T}$. aestivum) whereas other fungi formed only $40 \%$ of ECMs (Tab. $\mathrm{S} 1$ in Supplementary material). ECMs of $T$. aestivum and $T$. brumale were never found mixed in the same soil core (Fig. 3a). Tuber brumale ECMs were abundant in samples $D$ $(\sim 70 \%)$ although they were also found in samples $B$, collected $1 \mathrm{~m}$ far from the $T$. aestivum plants (Fig. 3a, Fig. S2). ECMs of T. aestivum were found in only 3 out of 6 plant rows, where it successfully expanded its colonization only as far as the samples collected along the transect midline (samples C, Fig. S2). ECMs of T. melanosporum were never detected in this transect. ECMs formed by other fungi were absent in 5 out of 18 samples where T. aestivum (4 samples) and T. brumale (1 sample) dominated.

ERM of the target truffle species was detected in 24 out of the 30 analysed soil samples (Fig. 3b). Tuber brumale and T. aestivum were exclusively found in 15 and 6 samples, respectively, and occurred together in only three samples collected along the transect midline (samples C). In contrast to $T$. brumale, T. aestivum ERM was never detected in soil samples col-

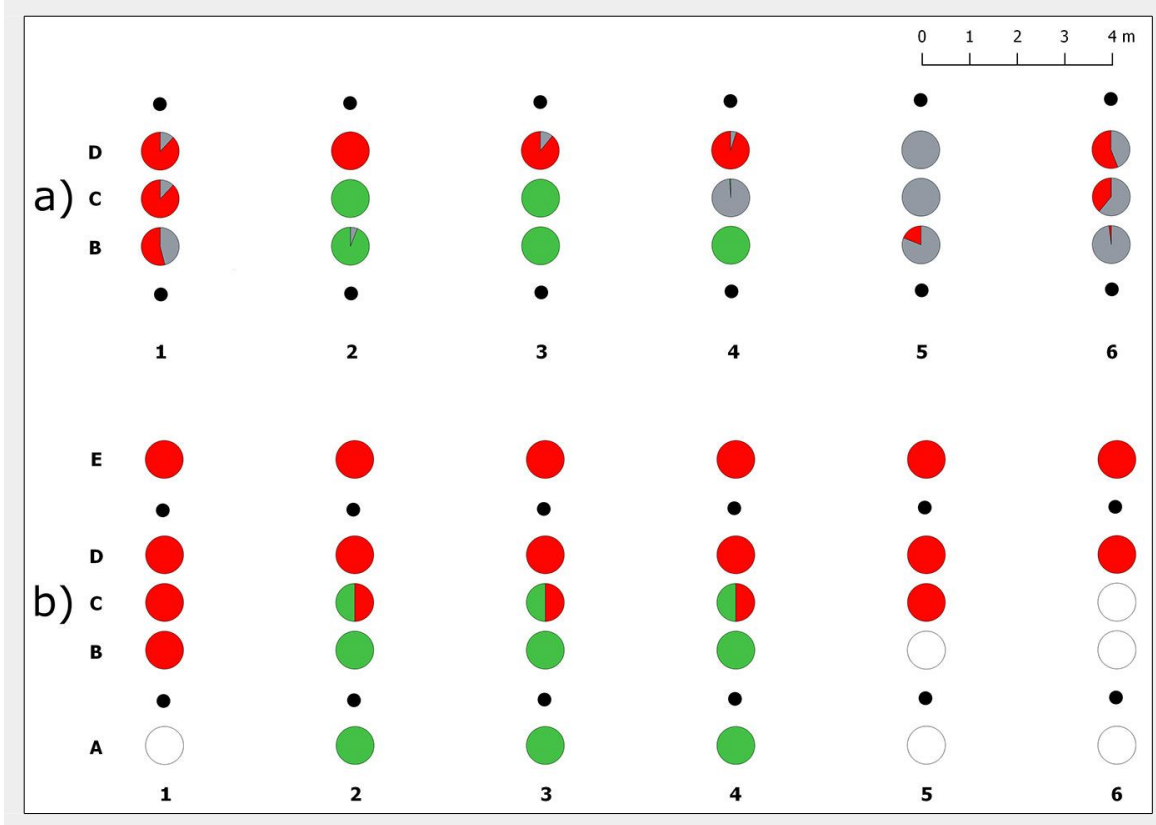

Fig. 3 - Spatial distribution of truffle ERMs and ECMs in the transect I (aest/brum). (a) Percentages of ectomycorrhizal colonization of the inoculated truffle species and native ectomycorrhizal fungi in each sample, from B to C; (b) presence/absence of the truffle ERMs in each sample, from A to E. (red): Tuber brumale; (green): Tuber aestivum; (gray): ECMs formed by other fungi; (white): no truffle mycelia; (black dots): host plants. 


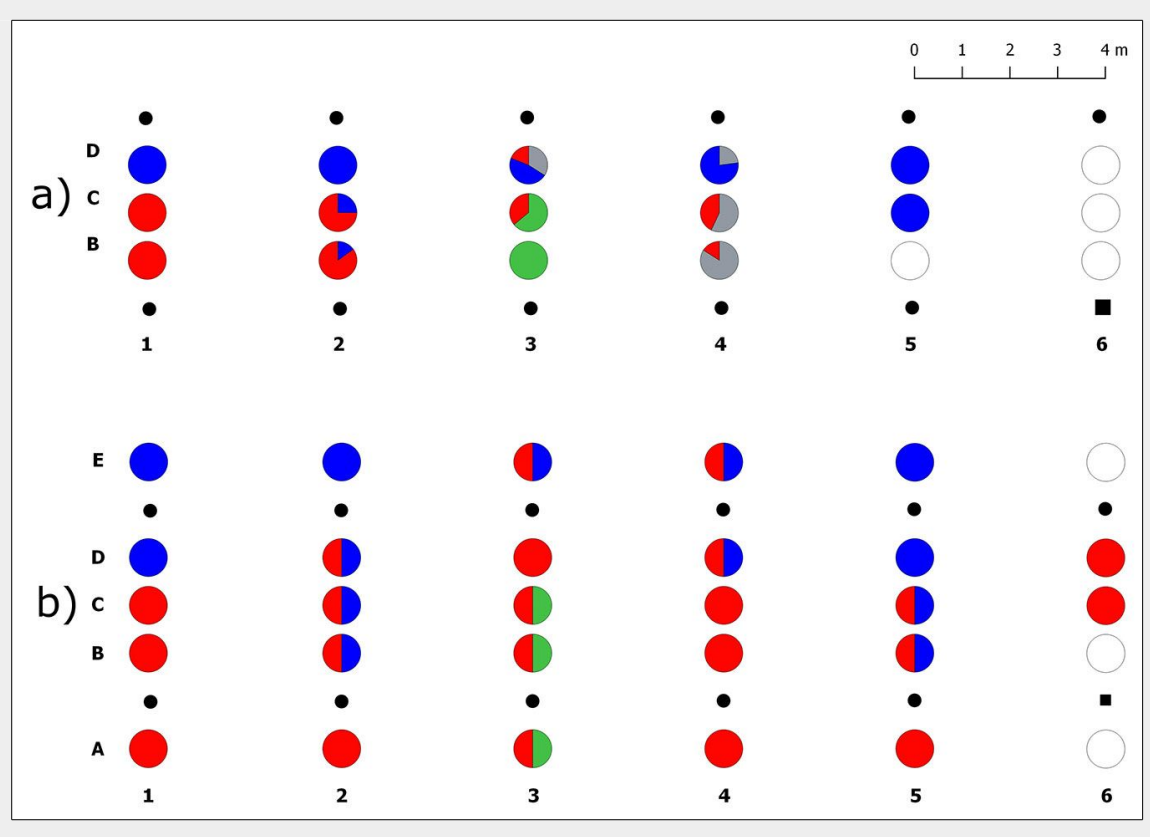

Fig. 4 - Spatial distribution of truffle ERMs and ECMs in the transect II (brum/mela). (a) Percentages of ectomycorrhizal colonization of the inoculated truffle species and native ectomycorrhizal fungi in each sample, from B to C; (b) presence/absence of the truffle ERMs in each sample, from A to E. (red): Tuber brumale; (green): Tuber aestivum; (blue): Tuber melanosporum; (gray): ECMs formed by other fungi; (white): no truffle mycelia; (black dots): host plants; (black square): dead host plant.

lected $1 \mathrm{~m}$ far from the $T$. brumale plants (types D and E) and it was completely absent in the whole sample sets (types A to E) of half plant rows. Soil samples collected within the two brûlés in this transect did not have ECMs or ERM of T. brumale.

\section{Transect II - brum/mela}

A total of 4310 ECMs were counted in 14 soil samples collected in the brum/mela transect. No roots were found in three soil samples, all collected close to the T. brumale dead plant in row 6. ECMs of the target Tuber species amounted to about $62 \%$, whereas the remaining 38\% was formed by other ectomycorrhizal fungi (Tab. S2 in Supplementary material). Tuber brumale dominated the community in this transect with $35 \%$ of ECMs, while T. melanosporum reached $27 \%$ (Fig. 4 a). ECMs of both species showed the same frequency but they cooccurred in only three soil cores. Tuber me lanosporum was mainly found in samples collected $1 \mathrm{~m}$ far from the trees inoculated with this species (type D), whereas T. brumale was mainly found in samples $B(1 \mathrm{~m}$ far from its plants) and $C$ (transect midline - Fig. S2 in Supplementary material). ECMs of T. aestivum ( $26 \%$ in total) were also found in two soil cores collected close to a T. brumale inoculated seedling in row 3 . One of these samples (type C) showed ECMs of both T. aestivum and T. brumale.

ERM of the target truffle species was detected in all the 28 analysed soil samples (Fig. 4b). Tuber brumale DNA was amplified in $\sim 90 \%$ of samples including those collected $1 \mathrm{~m}$ far from the T. melanosporum plants (types $D$ and $E$ ). However, five of these samples had a little amount of $T$. brumale mycelium with respect to that of $T$. melanosporum since its DNA was not amplified by multiplex PCR. T. melanosporum ERM was found in 13 soil cores, $~ 61 \%$ of which occurred together with $T$. brumale. The presence of $T$. aestivum DNA was detected in three soil cores, in row 3, where its ECMs were also found. Soil samples collected within the brûlé in this transect did not have ECMs or ERM of T. brumale.

No truffle ECMs and ERMs different from the inoculated species were detected in the soil samples collected within T. melanosporum and T. brumale plots.

\section{Discussion}

Tuber brumale has often been considered as a common contaminant in commercial truffières throughout Europe (Merényi et al. 2016). The competitive interactions between $T$. brumale and the other valuable black truffles were usually studied by targeting ECMs (Benucci et al. 2011) and, to a lesser extent, soil mycelium (Belfiori et al. 2012). Here, for the first time, we evaluated the spatial distribution of $T$. brumale against both $T$. aestivum and T. melanosporum in the same experimental site and cultural conditions, by targeting either their ECMs or ERM.

In general, the ERMs of the three target species were more diffuse than their respective ECMs, a trend particularly evident for T. brumale. Moreover, different truffle ERMs co-occurred in a number of soil cores much higher than the respective ECMs.

Fourteen years after the establishment of the investigated orchard, the competition for space among the three black truffle species seems to be almost confined to the transect areas. Tuber aestivum and T. melanosporum ECMs and ERM were only partially replaced in the transects and T. brumale does not appear to colonize the other truffle plots. This consideration is also supported by the distribution of the brûlés in the truffle plantation. These characteristic areas devoid of vegetation are much more evident in T. aestivum and T. melanosporum than $T$. brumale growth sites (Olivier et al. 2012). In our plantation, brûlés were completely absent within $T$. brumale plot and rare within the transect areas, whereas they were visible around almost all the plants within T. aestivum and T. melanosporum plots. Further confirmation of this hypothesis was obtained by the analyses of ECMs and ERM sampled within the T. melanosporum plot.

ECMs formed by other fungi were less abundant than those of the introduced truffles. The highest diversity and abundance of these fungi were found in the aest/brum transect, where three mature ectomycorrhizal trees at the edge of T. aestivum plot might have facilitated the colonization of truffle plants. This method of colonization by native ectomycorrhizal fungi has been discussed by several authors (Sourzat \& Dubiau 2001, Chevalier \& Sourzat 2012), who consider native host trees as one of the first issues to solve when a new truffle plantation has to be established.

Competition between $T$. brumale and $T$. aestivum has been only poorly investigated. ECMs of T. brumale have been found in T. aestivum plants (Baciarelli-Falini 2005, Zambonelli et al. 2005, Benucci et al. 2011) but specific studies supporting the possibility that these species can significantly replace each other in cultural or natural conditions have never been carried out. In our study site, ECMs and ERM of T. brumale showed a more even distribution than those of T. aestivum that, conversely, dominated a single soil patch in the centre of the aest/brum transect. The lack of T. aestivum ECMs and ERM in half the plant rows could be due to the gradual soil and root colonization of $T$. brumale or, more likely, of native ectomycorrhizal fungal species. Tuber aestivum ECMs and ERM were also found in three soil samples in the brum/ mela transect. In this case too, T. aestivum dominated a soil patch (smaller than the previous one) where only T. brumale co-occurred both as ECMs and ERM. These truffle species seem to adopt two opposite ecological strategies. As a matter of fact, $T$. aestivum appears to be less efficient in soil exploration than $T$. brumale but its presence strongly reduces the ectomycorrhizal fungal diversity, as also reported by other authors (Sourzat 2011, Belfiori et al. 2012). The presence of $T$. aestivum in the brum/ mela transect may be explained as the consequence of a cross contamination during nursery mycorrhization (lotti et al. 2012, Linde \& Selmes 2012) rather than a myce- 
lium or spore movement from the aest/ brum transect.

Tuber brumale has been ranked by several authors as a damaging species for truffle plantations (Martin-Santafe et al. 2014), able to displace T. melanosporum and reduce its productivity (Chevalier \& Frochot 1997, Callot et al. 2001, Lefevre \& Hall 2001, Riousset et al. 2001, Ricard 2003, Sourzat 2005, Olivier et al. 2012). It is considered so threatening that cultural practices in T. melanosporum plantations in France are mostly devoted to reducing its presence in the soil (Sourzat \& Dubiau 2001, Olivier et al. 2012).

In this study, T. brumale was never found invading $T$. melanosporum, although in some plant rows its ECMs expanded up to the sampling points closest to T. melanosporum plants. Tuber brumale ERM was found in two cores collected in the sampling points beyond the T. melanosporum plants, mixed together with T. melanosporum ERM. At the same time, however, T. melanosporum is still well represented both as ECMs and ERM inside the transect.

Competition between black truffles mostly depends on a number of edaphic factors, such as organic matter content and soil $\mathrm{pH}$. In the truffle plantation under investigation, the organic matter percentage is pretty low (1.2\%) and $\mathrm{pH}$ is $>7.5$, conditions that could have prevented $T$. brumale from colonizing the T. melanosporum plot. Several authors (Jaillard et al. 2016, Callot et al. 2001) claim that a low level of organic matter favours $T$. melanosporum rather than $T$. brumale. Moreover, T. melanosporum has a better development in alkaline soils with $\mathrm{pH}$ that ranges between 7.5 and 8.3 (Jaillard et al. 2016), while the optimal $\mathrm{pH}$ for $\mathrm{T}$. brumale is 6.5 (Bratek et al. 2001). The host species may also promote the competitiveness of one or the other Tuber species even if, in this case, the results in literature are more ambiguous. Some studies reveal that T. melanosporum proved to be more competitive on Quercus spp., contrary to $T$. brumale which prefers C. avellana (Chevalier \& Sourzat 2012, Donnini et al. 2001, Baciarelli-Falini et al. 2010). Another condition that might have also prevented the diffusion of T. brumale is the no-tillage condition adopted in the truffle plantation. In fact, soil tillage is considered able to favour the propagation of Tuber competing species (Chevalier \& Sourzat 2012).

\section{Conclusions}

In this study site, $T$. brumale was not able to spread out into the T. aestivum and $T$. melanosporum plots and the competition seemed to be confined to the transect areas. When the selection of the plantation site is appropriate for T. aestivum and T. melanosporum, the main issue is the risk of nursery contamination, the primary cause of subsequent contaminations in the field (Linde \& Selmes 2012). It is therefore crucial to carefully monitor the quality of both the spore inoculum and the Tuber mycor- rhized plants before the establishment of the plantation. The use of mycelial inoculated plants, which recently proved to be successful with $T$. borchii cultivation (lotti et al. 2016), could also be a valid solution because mycelium has several advantages over spore inoculum, such as fewer contamination risks and higher percentages of root colonization.

\section{Aknowledgements}

The authors would like to thank Gianluigi Gregori and Danilo Tognetti of ASSAM (Agenzia Servizi Settore Agroalimentare Marche, Osimo, AN, Italy) for providing climate data of the study area and Dr. Susan West (Arancho Doc, translation and Localization Services) for revising the English style of the manuscript.

\section{References}

Agerer R (1995). Anatomical characteristics of identified ectomycorrhizas: an attempt towards a natural classification. In: "Mycorrhiza: Structure, Function, Molecular Biology and Biotechnology" (Varma AK, Hock B eds). Springer, Berlin, Germany, pp. 685-734.

Baciarelli-Falini L (2005). Prime osservazioni sulla sostituzione delle micorrize di Tuber nelle tartufaie coltivate [First observations of replacement of Tuber mycorrhizas in cultivated truffle orchards]. In: Proceedings of the "Seminario sullo Stato Attuale della Tartuficoltura Italiana" (Bencivenga M, Donnini D, Gobbini A eds), Spoleto-Norcia (Italy), 21-22 Feb 2004. Associazione "il Tartufo nel 2000", Gruppo Micologico "Valle Spoletana", Norcia, Italy, pp. 75-80. [in Italian] Baciarelli-Falini L, Bencivenga M, Donnini $D, D i$ Massimo G (2010). Research results in truffle beds of the Umbria region. In: Proceedings of the " 3 rd International Conference on Truffles" (Donnini D ed). Spoleto (Italy) 25-28 Nov 2008. Comunità Montana dei Monti Martano, Serano e Subasio, Italy, pp. 577-589. [in Italian]

Belfiori B, Riccioni C, Tempesta S, Pasqualetti M, Paolocci F, Rubini A (2012). Comparison of ectomycorrhizal communities in natural and cultivated Tuber melanosporum truffle grounds. FEMS Microbiology Ecology 81: 547-561. - doi: 10.1111/j.1574-6941.2012.01379.x

Bencivenga M, Donnini D, Di Massimo G (1992). Analysis of Tuber melanosporum mycorrhizae in an 11-year-old truffle-bed. Micologia e Vegetazione Mediterranea 7: 159-171.

Benucci GMN, Raggi L, Albertini E, Grebenc T, Bencivenga $M$, Falcinelli $M$, Di Massimo $G$ (2011). Ectomycorrhizal communities in a productive Tuber aestivum Vittad. orchard: composition, host influence and species replacement. FEMS Microbiology Ecology 76: 170-184. - doi: 10.1111/j.1574-6941.2010.01039.x

Bever J (2002). Host-specificity of AM fungal population growth rates can generate feedback on plant growth. Plant and Soil 244: 281290. - doi: 10.1023/A:1020221609080

Bratek Z, Bagi I, Paradi I, Vikor J (2001). Differentiation among truffle species based on habitat preferences. In: Proceedings of the $5^{\text {th }}$ International Conference "Science et Culture de la Truffe" (Courvoisier M, Olivier JM, Chevalier G eds). Aix-en-Provence (France) 4-6 Mar 1999.
Federation Française des Trufficulteurs, Paris, France, pp. 193-195.

Callot G, Daignieres Y, Fernandez D, Raymond M, Salducci $X$ (2001). Effect of soil conditions on the fruiting of Perigord truffle (Tuber melanosporum). In: Proceedings of the $5^{\text {th }}$ International Conference "Science et Culture de la Truffe" (Courvoisier M, Olivier JM, Chevalier G eds). Aix-en-Provence (France) 4-6 Mar 1999. Federation Française des Trufficulteurs, Paris, France, pp. 257-259.

Chevalier G, Frochot H (1997). La truffe de Bourgogne [The Burgundy truffle]. Pétrarque, Levallois-Perret, France, pp. 257. [in French]

Chevalier G, Sourzat P (2012). Soils and techniques for cultivating Tuber melanosporum and Tuber aestivum in Europe. In: "Edible Ectomycorrhizal Mushrooms" (Zambonelli A, Bonito GM eds), Soil Biology series, vol. 34, SpringerVerlag, Berlin-Heidelberg, Germany, pp. 163189. - doi: $10.1007 / 978-3-642-33823-6 \_10$

Dahlberg A (2001). Community ecology of ectomycorrhizal fungi: an advancing interdisciplinary field. New Phytologist 150: 555-562. - doi: 10.1046/j.1469-8137.2001.00142.x

De Miguel AM, Agueda B, Sánchez S, Parladé J (2014). Ectomycorrhizal fungus diversity and community structure with natural and cultivated truffle hosts: applying lessons learned to future truffle culture. Mycorrhiza 24: 5-18. - doi: 10.1007/s00572-013-0554-3

Donnini D, Baciarelli-Falini L, Bencivenga $M$ (2001). Analysis of mycorrhization in over 12 year-old cultivated truffle beds of $T$. melanosporum Vittad. under various soil and climate conditions. In: Proceedings of the $5^{\text {th }}$ International Conference "Science et Culture de la Truffe" (Courvoisier M, Olivier JM, Chevalier G eds). Aix-en-Provence (France) 4-6 Mar 1999. Federation Française des Trufficulteurs, Paris, France, pp. 437-440.

Granetti B, Angelini P (1992). Competition between some ectomycorrhizal fungi and Tuber melanosporum in a cultivated truffle bed. Micologia e Vegetazione Mediterranea 7: 173-188. Gryndler M, Trilčová J, Hršelová H, Streiblová E, Gryndlerová H, Jansa J (2013). Tuber aestivum Vittad. mycelium quantified: advantages and limitations of a qPCR approach. Mycorrhiza 23: 341-348. - doi: 10.1007/s00572-012-0475-6

Guerin-Laguette A, Cummings N, Hesom-Williams N, Butler R, Wang Y (2013). Mycorrhizas analyses in New Zealand truffières reveal frequent but variable persistence of Tuber melanosporum in co-existence with other truffle species. Mycorrhiza 23: 87-98. - doi: 10.1007/s005 72-012-0450-2

Hall I, Brown G, Zambonelli A (2007). Taming the truffle. The history, lore, and science of the ultimate mushroom. Timber Press, Portland, OR, USA, pp. 304. [online] URL: http://www.fs. fed.us/pnw/pubs/journals/pnw_2008_trappeoo 1.pdf

lotti M, Leonardi M, Oddis M, Salerni E, Baraldi E, Zambonelli A (2012). Development and validation of a realtime PCR assay for detection and quantification of Tuber magnatum in soil. BMC Microbiology 12: 93-101. - doi: 10.1186/1471-218012-93

lotti M, Piattoni F, Hall IR, Zambonelli A (2016). First evidence for truffle production from 
plants inoculated with mycelial pure cultures. Mycorrhiza 26: 793-798. - doi: 10.1007/s00572016-0703-6

lotti M, Zambonelli A (2006). A quick and precise technique for identifying ectomycorrhizas by PCR. Mycological Research 110: 60-65. - doi: 10.1016/j.mycres.2005.09.010

Jaillard B, Oliach D, Sourzat P, Colinas C (2016). Soil characteristics of Tuber melanosporum habitat. In: "True Truffles (Tuber spp.) in the world" (Zambonelli A, lotti M, Murat C eds). Soil Biology series, vol. 47, Springer International Publishing, Cham, Switzerland, pp. 169190. - doi: 10.1007/978-3-319-31436-5_11

Kennedy P (2010). Ectomycorrhizal fungi and interspecific competition: species interactions, community structure, coexistence mechanisms, and future directions. New Phytologist 187: 895-910. - doi: 10.1111/j.1469-8137.2010.033 99. $\mathrm{x}$

Koide R, Xu B, Sharda J, Lekberg Y, Ositguy N (2005). Evidence of species interactions within an ectomycorrhizal fungal community. New Phytologist 165: 305-316. - doi: 10.1111/j.14698137.2004.01216.x

Lefevre CK, Hall IR (2001). The status of truffle cultivation: a global perspective. Acta Horticulturae 556: 513-520. - doi: 10.17660/ActaHortic. 2001.556.75

Linde CC, Selmes H (2012). Genetic diversity and mating type distribution of Tuber melanosporum and their significance to truffle cultivation in artificially planted truffières in Australia. Applied and Environmental Microbiology 78: 6534-6539. - doi: 10.1128/AEM.01558-12

Martin-Santafe M, Perez-Fortea V, Zuriaga P, Barriuso J (2014). Phytosanitary problems detected in truffle cultivation in Spain. Forest System 23: 307-316. - doi: 10.5424/fs/2014232-04900 Mello A, Cantisani A, Vizzini A, Bonfante P (2002). Genetic variability of Tuber uncinatum and its relatedness to other black truffles. Environmental Microbiology 4: 584-594. - doi: 10.1046/j.1462-2920.2002.00343.x

Merényi Z, Varga T, Bratek Z (2016). Tuber brumale: a controversial Tuber species. In: "True Truffles (Tuber spp.) in the world" (Zambonelli A, lotti M, Murat C eds). Soil Biology series, vol. 47, Springer International Publishing, Cham, Switzerland, pp. 49-68. - doi: 10.1007/978-3-31931436-5_4

Nara K (2006). Ectomycorrhizal networks and seedling establishment during early primary succession. New Phytologist 169: 169-178. - doi: 10.1111/j.1469-8137.2005.01545.x

Olivier JPM, Savignac JC, Sourzat P (2012). Truffe et trufficulture [Truffles and trufficulture]. FANLAC, Périgueux, France, pp. 400. [in French]

Parladé J, De la Varga H, De Miguel AM, Sáez R, Pera J (2013). Quantification of extraradical mycelium of Tuber melanosporum in soils from truffle orchards in northern Spain. Mycorrhiza 23: 99-106. - doi: 10.1007/s00572-012-0454-y

Peay KG, Bruns TD, Kennedy PG, Bergemann SE, Garbelotto M (2007). A strong species-area relationship for eukaryotic soil microbes: island size matters for ectomycorrhizal fungi. Ecology Letters 10: 470-480. - doi: 10.1111/j.1461-0248.20 $07.01035 . x$

Ricard JM (2003). La truffe. Guide technique de trufficulture [The truffle: technical guide for truffle cultivation]. Centre Technique Interprofessionnel des Fruits et Légumes, Paris, France, pp. 268. [in French]

Riousset LG, Chevalier G, Bardet MC (2001). Truffles d'Europe et de Chine [Truffles of Europe and China]. INRA, Paris, France, pp. 155. [in French]

Rubini A, Paolocci F, Granetti B, Arcioni S (1998). Single step molecular characterization of morphologically similar black truffle species. FEMS Microbiology Letters 164: 7-12. - doi: 10.1111/j.15 74-6968.1998.tb13060.x

Smith SE, Read DJ (2008). Mycorrhizal symbiosis ( $3^{\text {rd }}$ edn). Academic Press, New York, USA, pp. 800.

Sourzat P (2005). Pressure of contamination mycorrhizal fungi against black truffle in spontaneous and cultivated truffières in France. In: Abstracts of the " $4^{\text {th }}$ International Workshop on Edible Mycorrhizal Mushroom" (Honrubia M, Morte A, Torrente P eds), Murcia (Spain) 28 Nov - 2 Dec 2005. Universidad de Murcia, Spain, pp. 116.

Sourzat P (2011). Black truffle cultivation and competing fungi. In: Proceedings of the " 7 th $I n-$ ternational Conference on Mushroom Biology and Mushroom Products (Savoie JM, Foulongne-Oriol M, Largeteau M, Barroso $G$ eds), Arcachon (France) 4-7 Oct 2011. INRA, Bordeaux, France, pp. 516-528. [online] URL: http://www. cabdirect.org/cabdirect/abstract/20123168959 Sourzat P, Dubiau JM (2001). Contamination by Tuber brumale in truffle plantations: observations, experimentations and strategies of cultivation protection; the example of a truffle plantation at Miers in the Lot department, France. In: Proceedings of the 5th International Conference "Science et Culture de la Truffe" (Courvoisier M, Olivier JM, Chevalier G eds), Aix-en-Provence (France) 4-6 Mar 1999. Federation Française des Trufficulteurs, Paris, France, pp. 466-468.

Turgeman T, Sitrit Y, Danai O, Luzzati Y, Bustan A, Roth-Bejerano N, Kagan-Zur V, Masaphy S (2012). Introduced Tuber aestivum replacing introduced Tuber melanosporum: a case study. Agroforestry System 84: 337-343. - doi: $10.1007 \mid$ s10457-011-9478-0

Zambonelli A, lotti M, Zinoni F, Dallavalle E, Hall $R$ (2005). Effect of mulching on Tuber uncinatum ectomycorrhizas in an experimental truffière. New Zealand Journal of Crop and Horticultural Science 33: 65-73. - doi: 10.1080/01140 671.2005 .9514332

Zambonelli A, Leonardi P, lotti M, Hall I (2017). Ecological and genetic advances in the cultivation of Tuber spp. Revista Fitotecnia Mexicana 40: 371-377.

Zampieri E, Murat C, Cagnasso M, Bonfante P, Mello A (2010). Soil analysis reveals the presence of an extended mycelial network in a Tuber magnatum truffle ground. FEMS Microbiology Ecology 71: 43-49. - doi: 10.1111/j.1574-6941. 2009.00783.x

\section{Supplementary Material}

Fig. S1 - View of the truffle plantation at the time of sampling. Detail of the first two plant lines in the T. melanosporum plot (a). T. melanosporum plants with the characteristic brûlé (b).

Fig. S2 - Mean percentage of truffle ECMs at 1,2 and $3 \mathrm{~m}$ from the trunk of plants mycorrhized by T. brumale (A and B), T. aestivum (C) and T. melanosporum (D) in the transects I (A and C) and II (B and D).

Tab. S1 - Ectomycorrhizas (ECM) and extraradical truffle mycelium (ERM) in the T. aestivum/T. brumale transect.

Tab. S2 - Ectomycorrhizas (ECM) and extraradical truffle mycelium (ERM) in the T. melanosporum/T. brumale transect.

Link:Ori_2785@supploo1.pdf 